\title{
IMPROVEMENT OF THE MECHANISM OF FINANCIAL SUPPORT SMALL INNOVATIVE ENTERPRISES BASED ON UNIVERSITIES
}

\author{
Dr Liudmila Gennadyevna Romanovich* \\ Belgorod State Technological University named after V.G. Shoukhov, Russia \\ Dr Yuri Anatolievich Doroshenko \\ Belgorod State Technological University named after V.G. Shoukhov, Russia \\ Dr Irina Vladimirovna Somina \\ Belgorod State Technological University named after V.G. Shoukhov, Russia \\ Dr Marina Alekseevna Romanovich \\ Belgorod State Technological University named after V.G. Shoukhov, Russia \\ Dr Viktoriya Nikolayevna Ryapukhina \\ Belgorod State Technological University named after V.G. Shukhov, Russia
}

The Russia, like the advanced foreign countries, and develops innovative ways. In the article the questions of improvement of the mechanism of financial support of small enterprises, organized on the basis of universities. The authors analyzed the positive international and Russian experience in this field and recommendations are given based on the results of implementation of certain provisions of the Belgorod State Technological University named after V. G. Shukhov (Russia, Belgorod).

Key words: Mechanism of financial support of innovation activity, Small innovative enterprises

\section{INTRODUCTION}

In modern times of social and economic development of the States has highlighted the issues associated with the intensification of innovative processes in the economy. For Russia, with considerable scientific and educational potential and insufficient volume of the world market of civil high-tech products, this topic is of particular relevance. The most important role in generating intellectual property and the organization of innovation processes belongs to the graduate school. One of the main directions of modern universities is to promote taken in the country of the policy of innovative development and competitiveness of regions through the creation of scientific and technological developments and the development of innovative solutions, commercialization and implementation in the real sector of the economy of regions and the country as a whole. The value and role of small business in the dynamics of innovation processes proven rich experience of foreign countries and Russia, has chosen an innovative way of development. If abroad small innovative enterprises at universities successfully since the middle of last century, in Russia the universities have started to introduce a similar model since 2009, qualifying in accordance with Federal law № 217-FL set up economic companies (economic partnerships).

Obvious and the need for the formation of an effective organizational and economic mechanisms of stimulation of innovative activity of small enterprises, organized on the basis of universities. Crucial to this process is the improvement of the mechanism of financial support of small enterprises, organized based on universities.

The analysis of results of the survey of small innovative enterprises at universities in the regions of the Russian Federation, in particular the Belgorod region (selective) and Yaroslavl regions (solid), the factors hindering the development of innovation in modern conditions. In particular, in the Belgorod region the factors hindering the development of innovation in enterprises are ranked in descending order as follows:

$1^{\text {st }}$ place - money stringency for implementation of innovative activity:

- stringency of proprietary monies - 48,98\%;

- lack of financial support from the state $-40,82 \%$; 
$2^{\text {nd }}$ place - the high cost of innovation is $38,78 \%$; $3^{\text {rd }}$ place - high economic risk $26,53 \%$ :

$4^{\text {th }}$ place - the lack of qualified personnel $-24,49 \%$ :

$5^{\text {th }}$ place - underdeveloped innovation infrastructure $-18,37 \%$;

$6^{\text {th }}$ place - the uncertainty of the economic benefits from the use of intellectual property - 16,33\%;

$7^{\text {th }}$ place - lack of legislative support innovative activities; the lack of organizations engaged in scientific and technological developments; low innovative potential of the organization - $14,29 \%$;

$8^{\text {th }}$ place - lack of information about new technologies $-10,2 \%$ :

$9^{\text {th }}$ place - low demand for new goods, works, services $-8,16 \%$ [01].

In the Yaroslavl region were surveyed 56 small innovative enterprises based on universities (so much reported in the region for the year 01.01 .2013 ). The lack of funds noted $37.5 \%$ of respondents, lack of stable demand for products and services $-31.3 \%$, the lowest level of state support $-18.8 \%$, lack of infrastructure in universities - 12.5\% [02].

Accordingly, the biggest problems for small innovative companies (in the first half of the rating) are: financial problems in the implementation of innovative activities related to the high cost of innovation; then - high risks and lack of stable demand characteristic of innovation; lack of skilled personnel and inadequate innovation infrastructure. The research results showed $[03,04,05]$ suggest that innovations in the early stages of the lack of support, high risk and low probability of return on invested capital. The distinguishing feature of investment as an economic category, in that they involve the receipt of income, thus avoiding high-risk and are aimed at liquidity, reliable, high-demand types of market activities. This contradiction is present in all countries of the world and the cause of financial difficulties, the development of innovative entrepreneurship. Bearers of this contradiction are the economic entity - small innovative enterprise that represents innovation and investment interests for enterprises - investors. It should be noted that even in 1960 at the International Conference dedicated to fundamental academic and industrial research conducted in the USA, noted that "for every dollar spent on fundamental and applied research, is needed 10 dollars to prepare a study for the production of goods and 100 dollars, to introduce them into the pro- duction and promotion of goods on the market, created as a result of the study " [06]. Especially big problems in the financing of innovative entrepreneurship (and these problems are typical for all countries) there are in the start-up stages of enterprises: require significant resources to the search of potential buyers and production, purchase of equipment, fine-tuning technologies and rent of premises. In starting businesses large financial companies are reluctant to invest. Only $10 \%$ of venture capital companies attract legal entities at the stage of its launch. This problem in the UK and in the USA is solved by the active involvement of venture capital for individuals (business angels). However, if business angels invest more than 5 years, they are exempt from taxes on income [07]. The Russian business angels do not yet have the benefits of a business subject to tax in per standard procedure as any services for organizations and population [08]. The result of investigation of positive experience in the UK financial support of small businesses based on universities showed that in this country the following scheme is used "universal challenge" for the financing of strategically important high-tech projects. For this purpose, a special fund in the amount of 20 million pounds from the budget and in the same amount of funds - due to the charitable organization. Enterprises of innovation based on universities substantiate a possibility of getting out of the fund up to 10 million pounds they develop business plans for projects. Also actively are implemented various forms of cooperation between small and medium-sized innovative enterprises, large companies [09]. For example, in Cambridge and Oxford have created several innovative parks, which provide support in coupling the ideas of scientists-inventors to prototype and organization of companies for the creation of a new product. The Grants are the main source of financial resources of enterprises of the industrial Park. Also in the Oxford trust company created technology venture capital to support entrepreneurs in the initial stages of their operations. The conclusion of contract for municipal purposes (states) with small innovative enterprises as an effective form of financial support paid off in many economically developed countries (Germany, Austria, the USA and others), which today is actively using it. Also of interest is the international experience of state guarantees ventures under bank loans. So, the government in the UK and the Netherlands pro 
vide a guarantee of $70 \%-75 \%$ of the outstanding loans in case the venture fails. In Germany and Finland also actively implemented these forms of support. [10] In Russia, the mechanism of financial support of small innovative enterprises based on universities is just being formed, and, of course, is important in this case to take into account the positive experience of countries the leaders in terms of innovation. Problems and underdeveloped a market of private risk capital causes a situation that financial support for small and medium-sized innovative businesses from the state is critical. In Russia, the state in modern conditions have to take on the role of institutions such as private venture capital funds, informal venture capital and compensate the unavailability of private finance in the "pressed" stage of development of innovative enterprises (the sotermed "market failures"). It can be concluded that in modern times the domestic starting small businesses mostly use the means of its founders (Table 1). As a rule, the personal savings of scientists - researchers in small volumes because of the high risk of innovative projects.

Table 1: The sources of opening (starting) capital of small innovative enterprises as in \% of total responses [11]

\begin{tabular}{|l|c|}
\hline Own funds of the founders* & 75 \\
\hline $\begin{array}{l}\text { Funds of the state venture capital fund or a } \\
\text { fund to support the commercialization }\end{array}$ & 27 \\
\hline $\begin{array}{l}\text { Funds of the private investors - individuals } \\
\text { (including relatives) }\end{array}$ & 16 \\
\hline Funds non-state specialized funds & 9 \\
\hline Bank credit & 7 \\
\hline Other forms of state support & 6 \\
\hline Other forms & 3 \\
\hline
\end{tabular}

*The sum of responses exceeds 100\%: allowed several answers

As follows from the Table, financial support programs play a less stickout role (in comparison with their own means of the founders) in the financing of technological projects in the stages of "pressed " (the early stage of development of innovative business project) and the development stage of the product (prototype development, patenting). The structure of the sources of startup capital, in our view, cannot be considered rational. It must be admitted that in the Russian Federation before now has not formed a market of free capital, which is interested in investing in small and medium-sized innovative enterprises. Most of the development of venture financing slows underdeveloped legal support of various aspects of investment support for innovation, the weak interaction of developers and investors, the shortage of experienced managers for innovative companies, and the lack of infrastructure finance risky projects.

The study of international and domestic experience proposed the following mechanism for financial support of innovative enterprises in universities, the implementation of which in combination will enhance the commercialization of result of intellectual activity (Figure 1) [12].

Based on an assessment results analysis of innovative potential of small businesses, organized in universities, the authors proposed the introduction of financial support for innovative enterprises (Figure 1) that allows them to develop dynamically on the basis of universities, taking into account the integrated approach to financing of small businesses at different stages of their development and active influence various market instruments of financial support from various sources:

- federal financial support instruments;

- regional instruments of financial support;

- instruments of financial support from the university;

- instruments of financial and credit support to banks;

- risk investment instruments of private venture funds and business angels;

- investment instruments of pension and insurance funds;

- financial instruments from the enterprise (business).

\section{CONCLUSION}

Draw attention on the individual elements of the mechanism should be allocated as follows:

In modern conditions of underdevelopment of venture capital investment is a system of grants can help to bring the results of research and development to commercialization of university research. This problem is particularly acute in the area of innovative projects in the early stages, where in most cases there are no prototypes, testing, documentation proving that the output will ensure the development of the given characteristics and properties, respectively, and no customer wants to risk the money. 


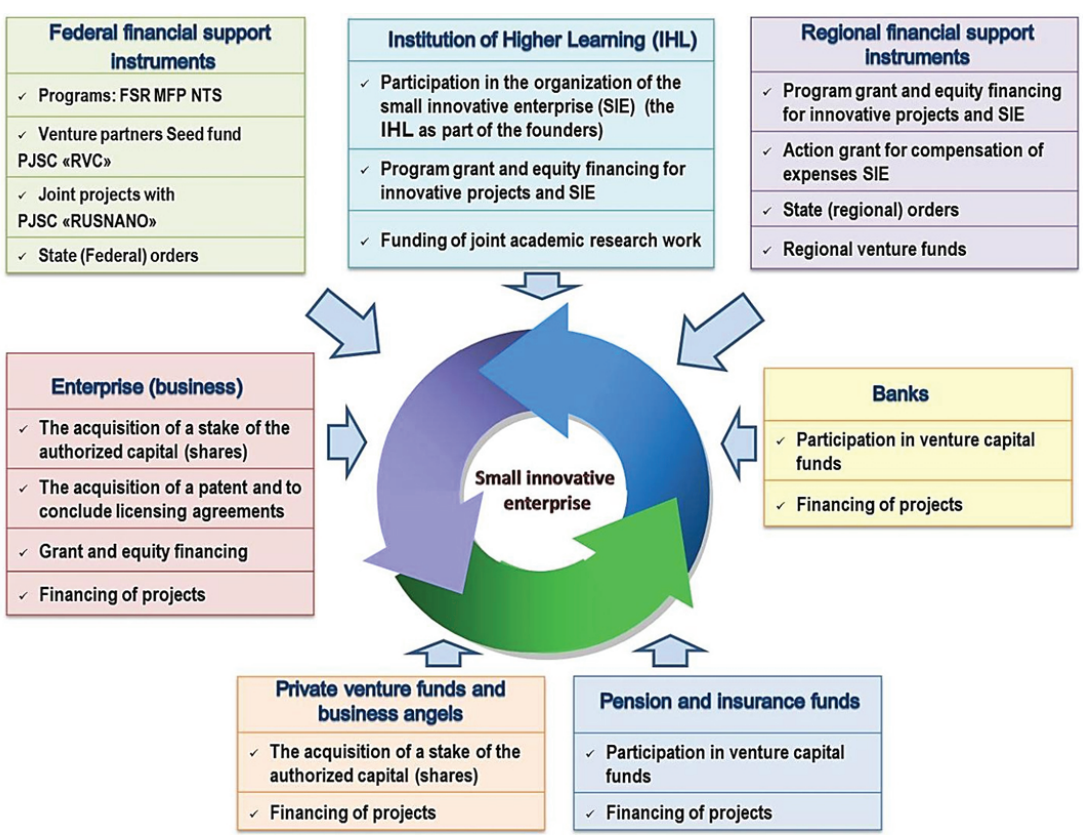

Figure 1: The Mechanism of financial support for innovative enterprises based on universities

Foreign investments are of great importance for the development of the national economy. However, it should be recognized that the more strategically important direction is to organize and develop its own venture capital industry. It is important to actively establish the mechanism of financial support of small innovative companies from the universities on the basis of which they are developing: through programs of grant and equity financing of innovative projects, including through specially created funds finance the implementation of joint research, development and operations.

\section{ACKNOWLEDGEMENTS}

The article was published with the financial support from Ministry of Education and Science of the Russian Federation within the framework of state assignment to the project \#26.1511.2014K "Theory and methodology of managing innovational and investment processes in small business enterprises."

\section{REFERENCES}

1) Resolution of the Government of the Belgorod region on January 25, № 27-PP (2010) On the Strategy for Socio-Economic Development of the Belgorod region for the period till 2025.

2) Ilishin, A.B., 2013. Regional model of the commercialization of intellectual products created by small innovative enterprises. Environmental Nanotechnology Manufacturing, 6 (25).

3) Doroshenko, Y.A., Somina, I.V., 2012. Modeling the impact of innovative activity. Sociallyhumanitarian knowledge 8: 172-177.

4) Doroshenko, Y.A., Komissarov, S.A., 2012. Small company as the subject of innovative business. Socially-humanitarian knowledge, 8: 165-171.
5) Doroshenko, Y.A., Somina, I.V., Komissarov, S.A., 2013. Sources of Financing and Innovative and Investment Activity of Small Enterprises World Applied Sciences Journal, 25 (6): 975-982.

6) Proceedings of a Conference on Academic and Industrial Basic Research. Prinston, 1960, 4.

7) Bochkarev, A. Experience venture business in the UK. Investments in Russia. Electronic version http://www.maplaza.ru/articles/article65.htm

8) Romanovich, M.A, Rudichev, A.A. Romanovich, L.G., 2011. Venture investment in innovative enterprises abroad and in Russia. Bulletin of Belgorod State Technological University named after V.G. Shukhov, 4: 124-127.

9) Romanovich, L.G., Rudichev, A.A. Romanovich, M.A., Lycheva A., 2013. Incentives for innovative activity of young scientists on the basis of higher educational institutions in Russia. Experience of Belgorod State Technological University named after V.G. Shukhov. World Applied Sciences Journal, 25 (12): 1754-1757.

10) Romanovich, M.A., Evtushenko, E.I., Romanovich, L.G., 2013. Stimulating innovationbased institutions of higher education. Bulletin of Belgorod State Technological University named after V.G. Shukhov, 5: 150-152.

11) Competing for the Future Today: a new innovation policy Russia, 2010. M: Support of Russia, Sberbank of Russia.

12) Romanovich, M.A., 2014. Improving the mechanism of stimulation of innovative activity of small enterprises based on university. Thesis abstract on competition of a scientific degree of candidate of economic sciences. Belgorod State Technological University named after V.G. Shukhov, 188.

Paper sent to revision: 09.04.2015.

Paper ready for publication: 12.09.2015. 